\title{
Philosophical Remarks of Nikolai Nikolev
}

\section{Философские замечания Николая Николева}

Adam Drozdek

(Pittsburgh, USA)

\begin{abstract}
:
Nikolai Nikolev, a poet and playwright, made in his extensive notes that accompany his Liro-didactic letter, many interesting philosophical and theological observations: on the nature of metaphysics, on the relation of metaphysics to other areas of knowledge, on the unknowability of God, and on the source and nature of human knowledge. His philosophical remarks are important considering a rather weak philosophical developments in Russia in the 18th century.
\end{abstract}

\section{Key words:}

Nikolev; philosophy; metaphysics; theology

\section{Абстракт:}

Николай Николев, поэт и драматург, сделал в своих обширных заметках, которые сопровождают его Лиро-дидактическое послание, многие интересные философские и богословские наблюдения: о природе метафизики, о отношении метафизики к другим областям знания, о непознаваемости Бог, и об источнике и природе человеческого знания. Его философские замечания важны с учетом довольно слабых философских событий в России в XVIII веке.

\section{Ключевые слова:}

Николев; философия; метафизика; богословие 
Nikolai Petrovich Nikolev (1758-1815) was one of the most popular literary figures of the end of 18 th century Russia, a prolific poet and playwright, whose poetry was published in five volumes. One of his works was Liro-didactic letter, a poetical homage to his supporter, princess Dashkova. The versified letter itself occupies $5^{1}$ pages, but the notes are sprawling over 269 pages. ${ }^{1}$ The notes include his observations on most of the areas of science of his day: physics, biology, chemistry, medicine; they include discussion on poetry and literature, but also notes on philosophy and theology. ${ }^{2}$ They were dismissed by some because "apparently [Nikolev] wanted ... to shine with his profound understanding in all branches of scientific knowledge" 3 and, generally, he naively believed that in the notes accompanying his poetry "the bottomlessness of knowledge and scholarship is hidden." 4 Be it as it may, this does not diminish the value of these notes. Also, considering the arid philosophical landscape in Russia in the 18th century, they deserve some attention.

Metaphysics or higher physics or the science of supreme existence (преествственница) is "science leading to the knowledge about immaterial beings. God, the soul, actions (произдействия) of the spirit, [and] invisible attributes of bodies." In this, Nikolev appears to have referred to the definition of Thümmig, ${ }^{5}$ which was mentioned in Baumeister's Metaphysics translated from Latin into Russian. ${ }^{6}$ Nikolev also mentioned a definition of some French authors who called metaphysics the science of ideas or concepts. Nikolev himself settled on the definition of metaphysics as the spiritual science since ideas are present in the spirit (3.242). ${ }^{7}$ Physics leads from the visible to the invisible; metaphysics from the invisible to the visible. Physics uses innumerable

1 The first time, only the Letter was published entitled Лирическое послание, Новыя ежемесячныя сочинения 1791, pt. 6o, pp. 5-39; entitled Лиро-дидактическое послание, it appeared also in 1795 in his Творении, vol. 3, pp. 91-142 along with the notes, Пополнительныя примечания, on pp. 145-414.

2 In their articles, Altshuller and Gneusheva concentrated only on literary quarrels of the age related to the Letter, ALTŠULLER, M. G.: «Liro-didaktičeskoje poslanije» N. P. Nikoleva. In: JAMPOL'SKIJ, I. G. (ed.): Russkaja literatura. Leningrad: Izdatel'stvo Leningradskogo universiteta 1968, pp. 208-214; GNEUŠEVA, R. D.: «Liro-didaktičeskoje poslanije» $i$ «Položitel'nyje primečanija» $k$ nemu kak èstetičeskij manifest N. P. Nikoleva. In: KUZ’MIČEV, I. K. (ed.): Struktura literaturnogo proizvedenija. Vladivostok: Izdatel'stvo Dal'nevostočnogo universiteta 1983, pp. 64-71.

3 ČEBYŠEV, A. A.: N. P. Nikolev (Istoriko-literaturnyj očerk). Filologičeskija zapiski 29 (1890), no. 3, p. 31.

4 AKSAKOV, S. T.: Literaturnija i teatral'nyja vospominanija. In: Sobranije sočinenij. Moskva: Izdanije A. A. Karceva 1902, p. 13.

5 Definiri adeo potest Metaphysica per scientiam entis et mundi in genere rerumque immaterialium. THÜMMIG, L. P.: Institutiones pilosophiae Wolfianae. Francofurti 1746, vol. 1, p. 38.

6 BAUMEJSTER, Ch.: Metafizika. Moskva: V Universitetskoj tipografii u Novikova 1789 [1764], p. 8.

7 Volume and page of Tvorenii Nikolaja Petroviča Nikoleva. Moskva: V Universitetskoj tipografii, u Chr. Ridigera i Chr. Klaudi 1795-[1798], vols. 1-5. 
tools to investigate nature, metaphysics uses only the spirit and thus the spiritual science. However, the latter definition is too broad since theoretical physics also uses only the spirit or the mind and so does logic, theology, philosophy, and, although not science, but something very important for Nikolev, a poet and a playwright-so does literature. A philosopher is "a man who knows the truth and acts according to the truth." To do it, one's ideas have to form a harmonious union which shows the truth to the spirit (255). And this is the role of metaphysics (256). Thus, the harmonious union of ideas appears to be the province of metaphysics. Would that mean that the disharmonious collection of ideas is not metaphysics? A harmonious union of ideas pondered by theoretical physicists is not metaphysics?

Each soul can understand itself and thus understand its Creator. Nikolev tried to make it clear why this should be. A metaphysician (the Soul-Metaphysician) would say, "I am! I know it by my perception; and what I know through it, I know through reasoning. What am I?-the triune being that forms a unity: Will, Reason, Sensation-these are my three powers: their union-this is my unity; this is I-the soul; this is where the three powers are perfectly inseparable and perfectly free in one being" (3.266). Inseparable: since the will is not devoid of sensation and reason; similarly with sensation and reason. Free: "since the will, accompanied by the two [other powers] and accompanying them, is independent as will." Each faculty can act independently of one another. This shows that "I am the soul, the center of the three inseparable powers.... This understanding about myself gives me also understanding about my infinite principle: since, to take my will, it is limitless; when I soar with my thinking reason, it is ubiquitous; when I turn to my senses-the flame of its love consumes everything: that I am not the principle of myself I know from the fact that I am a part of others like me and [I am] not the all-whole that fills everything" (267). This principle should be perfect: almighty according to my reason, supremely wise according to my will, supremely good according to my sensation-this is love itself. This being creates all by its omnipotence, just as I do with my will, arranges everything by its wisdom as I do with my reason, protects and cares about all though its love. It is God (268). The soul is the image and likeness of God who is its principle. As the image and likeness of God, I am closest to God. Thus, God is in me as in His image. This I know from my own unknowability and if an image is unknowable, how can God be known? (270). This is a rather perplexing conclusion: self-knowledge was supposed to lead to the knowledge of God, and yet a person cannot know oneself and thus cannot know God. Well, a person cannot have a perfect knowledge about oneself. We don't know the causes of properties of bodies: weight, transparency, softness, etc. (234). We know that our hand rises when we want it, but we don't know how the nature of the connection of the hand with the will (4.151); that is, how a mental act of the will causes a physical reaction of the hand. When it comes to the knowledge of nature, there are similar limitations: what is 
the nature of the power that gives the law of gravitation (3.237), we ask. Gravitation can be analyzed and measured with great precision, but why is there such a thing as gravitation? Could the world have been created without it? Similarly with our bodies and souls: natural and psychological knowledge can only go so far. There are limits which reason cannot cross.

"If the entire nature shows ... constantly that God exists; if reason itself (not to mention the feeling suppressed by it, this entity inside me which at one time exclaims-I am and God is), if this proud reason that wants to destroy God unintentionally finds him everywhere, then this inevitably gives us knowledge about his attributes; it proclaims that he is omnipotent, supremely wise, good, supremely perfect-what else?-Unknowable (Непостижим), and this attribute of his found proud reason itself: soaring on the wings of thought in the footsteps of this being, flying higher and higher it couldn't finally reach the limit where God was hiding from its eyes, where reason, however fast were its wings, couldn't-couldn't reach this being and, having stopped, it was forced to say-God is unknowable" (3.263). The unknowability of God fits fairly well the apophatic theology advocated by Orthodoxy. The essence of God cannot be known with the human reason; human understanding of God is and will always be limited regardless of how far human reason can extend this understanding. Having determined that God is unknowable, the human reason would be foolish trying to know God (264), know fully, that is. Therefore, Nikolev can exclaim: "Unknowable being! / Your existence is known. / Everything is protected only by You, / The world-and my existence" (1.193). God is unknowable as to His essence, but His existence is known and so is His providential care for the world.

Apparently, the avenue leading from self-knowledge to God was designed by God Himself: to avoid errors, God "spoke and supreme wisdom was poured in words into all human ears: it enlightened from the outside so that the light residing inside, having received new strength, illuminated human soul more and more so that it could see more clearly, hear better, sense more strongly, act more vividly, and take delight from the overabundance of goods, would glorify their Giver, the first good, the first cause, the first love-the first all in all." There is thus already something residing inside of the human soul-at least the cognitive abilities and, perhaps, also some inborn knowledge which is enhanced by an influx of divine wisdom poured into humans (3.243).

Wisdom is poured into human ears, but the word of wisdom is also spoken by the language of nature (3.243), which leads directly to physico-theology frequently expressed by many Russian authors. If anyone doubts the existence of God, he should look around: "Order, harmony and makeup which I see in creation / Manifest in all its parts the Divine finger; / In their forms I find the essence of God, / The supreme beauty can be seen in their existence" (1.147). God thus speaks not only through the Scripture, "the blessed writings," but also through nature, "the book of being" (1.155). 
Thus, investigation of nature enhances faith. For example, Cassini investigated the sky but he did not want to destroy the Creator, but wanted to glorify Him more (3.210). Newton showed blind atheists that God exists, that He is the highest reason (215). However, woe to an overreach: knowledge of laws of nature leads to the recognition of how small people are (225). Reason proud of its accomplishments may want to go where it should not "to see the invisible, to reach the unreachable," in which case reason is not the success, but illness, madness and death. Physics just cannot explain everything (230).

Why does the reason go wrong and thus why does metaphysics can fall apart? There are three reasons for the demise of metaphysics. First, "man having forgotten the influence of the Ideas, forgot that they are poured into him and are not created by him; having forgotten it, he began to assume the latter for the former and then reason became the Leader, and senses [became] subordinated or the former [became] acting, the latter passive. The second cause follows from the first. Reason, having forgotten its principle, thought it was without principle," and thus independent, whereby reason became blind (3.258). The third reason follows from the first two: considering as cause what was not the true cause, reason took shadows for things, names for objects, forgot that names came after things and were given according to their properties, not properties were given to things according to their names (259). Materialists want to reject the Trinity without contemplating the meaning of the one Divinity in three persons say how three can be one and demand to show them a stick with one end or to show that 2 times 2 isn't four, whereby they would believe in the Trinity (260). Such thinking is a result of forgetting that names are given according to properties of things. No one should demand showing a stick with one end having called an object with two ends a stick (261). Reason concentrated on the appearance, on shadows; it forgot the First Number, e.g., it derived conclusions about God, soul, and itself from their names, not from their essences. "To destroy God, it invented words Self-existing Monads, Thinking Matter, Eternal Motion, the World-Soul, [Primal] Element Water, [Primal] Element Fire, and the like" (262).

When principal ideas are rejected, the image is dark; the mirror of the heart is forgotten, reason does not look into it and does not see itself, not seeing its own essence, but the surface (3.265). Thinking about itself as without principle, reason drew its conclusions from the outside "and not from its source or from its feeling; consequently, it reasoned without an assumption, without an inner point from which the spiritual Geometer or Metaphysician derives his designs ... to derive the visible-existing from the invisible-existing and to derive a conclusion about existing-knowable from existing-unknowable assumption" (266). That is, the paradoxical outcome of metaphysics would be that the unknowable is the source of the knowable-what we know is derived from what we do not know, at least not all, at least not about its 
essence. Self-knowledge, the knowledge about one's own will, reason, and sensation, leads to the recognition of the existence of the triune God, whose essence will always remain shrouded in mystery and yet as much or as little can be understood about God, this understanding becomes the firm foundation of all knowledge and thus of all life, personal, social, political, and otherwise. The unknowable God should thus be the ontological and epistemological starting point in Nikolev's view and this will allow people to know something about the world.

Although it remains rather unclear from Nikolev's remarks what metaphysics exactly is - a spiritual science is rather too broad a definition-he considered it to be the foundational science because it was the foundation of all science, of morality, true religion, and civic laws (3.256). He considered it to be father-science since "everyone knowing the essence of each science should inevitably honor with this name the science of Ideas, which I have understood under the name of seed transferred to mother to generate and reveal spiritual fruit. When Ideas are understood only by the spirit, then they are seeds of the divine Providence, this good which the Creator pours into his chosen vessels, that is, into free spirits. When these Ideas are contemplated upon and understood by the spirit or mind, then they are spiritual entities (лики) or words-thoughts of which creator-spirit is no other than the Metaphysician." When these ideas are ready to be shaped in nature or to be related to natural things, then father-science metaphysics gives these ideas as seeds to science-mother mathematics to shape spiritual seed in flesh through counting and measuring (288-289). In these rather nebulous statements, Nikolev seems to have meant that metaphysics is the most general science, most abstract and ideas or concepts generated by the metaphysician-or perhaps retrieved from one's own soul where God put them-have to be actualized in more concrete science and in specific areas, mathematics being one of them. The metaphysical ideas like seeds are submitted to other sciences which are germinated by them like mothers giving fruits related to the area of interest of these sciences. By mathematics Nikolev meant in particular "political arithmetic" used to improve governing (293), applied math, we would say today, although Nikolev concentrated on politics as the area of its application. From this, rather unaccountably and glibly, Nikolev went to the glorification of the Russian imperial system and to debunking a malicious rumor spread abroad that there was despotism in Russia under Catherine II (296). None of it also under Peter I, Peter-tsar the hero, tsar the lawgiver, tsar the father, tsar the master, "political mathematician, Descartes and Newton in the art of governing" (304).

Nikolev's idea of metaphysics as the father-science seems to have been inspired by Descartes' tree simile-after all, Nikolev considered Descartes' philosophy to be "the philosophy of a genius who came to the world to enlighten future ages" (3.203)-in which metaphysics is the roots, physics is the trunk, and all other sciences are the 
branches (preface to the first edition of Principles of philosophy). Before him, Bacon expressed the idea that metaphysics is mother of all sciences. And thus, the generality of ideas expresses by metaphysics is its distinguishing mark, and also, as Nikolev expressed it, the fact that the only means of general proofs are in metaphysics (3.257).

In Nikolev's view, no metaphysician can correctly judge about God and the soul without beginning his proofs concerning the relation of the spirit and body from the first cause, but beginning with "some Organic bodies or with Automata" (3.254). Apparently, causality, God, and the soul are three of the foundational ideas or concepts of metaphysics. By pointing to the necessity of the first cause, Nikolev ruled out some ideas concerning the eternity of the world. In his metaphysics, there is a cause of all that exists. "It is time for us to look into mental Chaos, to hear what strange subheavenly wisdom tells us about this primal cause-or great magnitude of our sins" (3.244). A wrong idea about the beginning of the world is not an innocent mistake; it is a sin. As he phrased it, the first sin called Ocellus Lucanus who lived before Moses, was about the eternity of the world, the first absurdity of human reasoning. In fact, Ocellus Lucanus lived in the 6th century BC and he did express his views about the eternity of the world in his book On the nature of the universe. The view was accepted by Aristotle: the world is eternal but it is directed by an eternal, rational being who is God and "having hidden the creator, he did not show us God, either" (245). In fact, Aristotle's Prime Cause does not direct anything; it is a final cause of the world; the world itself strives for this Cause's perfection. However, the introduction of the eternity of the world Nikolev saw as a way of denying God's existence and making man a machine and a measure of all things (1.173).

However, all systems that do admit the emergence of the world are not equally acceptable. Nikolev mentioned the atomism of Leucippus and Democritus who said that an infinity of atoms move in an infinite space and give rise to chaos, then winds, then worlds (3.246). Buffon used Newton's remark to say that planets and satellites are one 650th part of the mass of the solar system; there was a comet having enough matter to create planets; bodies were formed after the comets collision with the sun and by rotation they became spherical (248). How can great people occupy themselves with such absurdities?, commented Nikolev (249). In his view, those espousing such views simply miss the following axiom: "no being can understand principles of its own existence and of beings like itself; understanding is nothing else than the vision of its own reason; and because the ability to see or understand a rational being didn't receive before it already existed, then it can't understand or see how it began [to exist]; since how this which is can judge about what this is was, when it was not yet? or when this is was not [yet] I am? The latter can only understand what each I am, was, and each was [and] will be what it was and is; but [it can]not [understand] how it began [to exist] in the first cause." Nikolev adds to it that no philosopher so far noticed this 
axiom and he never saw it expressed by anyone (249). If no understanding about the past can be obtained then the scope of knowledge would be severely limited. Would history or geology be even possible? On the other hand, Nikolev's axiom appears to be self-directed: I cannot understand reasons of $m y$ own existence. Can I understand reasons of someone else's existence even if they are older than I am and so I did not witness their coming into being? What should be done, then? It seems that Nikolev called the searchers for truth to rely on revelation and on inborn knowledge, the outer revelation of the Scripture and the inner revelation of the heart. This allowed Nikolev to say, "That there is the Creator of everything I have no doubt; / [My] heart tells me about Him" (4.254); "In the depth of [my] heart I hear / The voice of God day and night" (1.281); and "Listen to the advice of the heart, / God speaks in there to you" (5.284); this is because God writes His message in the hearts of sinners just as He wrote it on the wall for Balthasar, but sinners constantly try to erase it, which only results in fear and longing (1.223). However, this writing is an ongoing divine undertaking: humans are not only born with some knowledge inscribed in their hearts, but God's providential care speaks through the heart during the person's lifetime. This has very important ethical consequences concerning the way people should conduct their lives, and Nikolev's spiritual poetry is replete with this aspect of the human-divine relationship.

Nikolev did not create any new philosophical system-he did not create any system considering the fact that he only provided a set of rather impressionistic philosophical observations. However, these observations, few as they are, are very interesting and it is rather regrettable that Nikolev did not devote more attention to metaphysics, philosophy, and theology. His poetry is saturated with some philosophy and a great deal of theological and religious observations, but he did not strive for any systematic presentation of his philosophical ideas. However, what he presented deserves more than cursory attention considering the dearth of philosophical work in Russia in the 18th century. There were few philosophical observations in works of ecclesiastics of the time. Many a time they were just lectures for the seminarians (e.g., Prokopovich, Konisskii). There are some noteworthy philosophical works of Bolotov, interesting discourses of Anichkov and Shcherbatov who concentrated on the immortality of the soul; there is Desnitskii who spoke about the philosophy of the law if only following Adam Smith, and Lomonosov who had only a few things to say about natural philosophy. Teplov wrote a rather undistinguished introductory book on philosophy and so did Kozel'skii. In this background and regardless of the poetic rapture in which his views are expressed, Nikolev's philosophical notes fair rather well as to their profundity notwithstanding his somewhat self-deprecating remark that he didn't consider himself a professor of philosophy, but only "a curious ignoramus" (3.319). Russia had to wait until the 19th and particularly until the zoth centuries to 
produce anything worthy of philosophical attention. One of the most important of these thinkers was Siemion Frank with his profound work, The unknowable and with his insistence of the importance of unknowability of God Nikolev could be considered a forerunner of this work.

\section{References:}

AKSAKOV, S. T.: Literaturnija i teatral'nyja vospominanija. In: Sobranije sočinenij. Moskva: Izdanije A. A. Karceva 1902.

ALTŠULLER, M. G.: «Liro-didaktičeskoje poslanije» N. P. Nikoleva. In: JAMPOL'SKIJ, I. G. (ed.): Russkaja literatura. Leningrad: Izdatel'stvo Leningradskogo universiteta 1968, pp. 208-214.

BAUMEJSTER, Ch.: Metafizika. Moskva: V Universitetskoj tipografii u Novikova 1789 [1764].

ČEBYŠEV, A. A.: N. P. Nikolev (Istoriko-literaturnyj očerk). Filologičeskija zapiski 29 (1890), no. 3.

GNEUŠEVA, R. D.: «Liro-didaktičeskoje poslanije» $i$ «Položitel'nyje primečanija» $k$ nemu kak èstetičeskij manifest N. P. Nikoleva. In: KUZ’MIČEV, I. K. (ed.): Struktura literaturnogo proizvedenija. Vladivostok: Izdatel'stvo Dal'nevostočnogo universiteta 1983 , pp. $64^{-71}$.

THUMMIG, L. P.: Institutiones pilosophiae Wolfianae. Francofurti 1746, vol. 1.

Tvorenii Nikolaja Petroviča Nikoleva. Moskva: V Universitetskoj tipografii, u Chr. Ridigera i Chr. Klaudi 1795-[1798], vols. 1-5.

\section{About the author Adam Drozdek}

Duquesne University, McAnulty College and Graduate School of Liberal Arts, Department of Mathematics and Computer Science, Pittsburgh, USA drozdek@duq.edu 
